\title{
Linguistic Alienation and Culture Subversion as Sociolinguistic Factors for Name Dropping and Change among the So-Called Yoruba Elites
}

\author{
Ogunwale, Joshua Abiodun (Ph.D), Bamigbade, Oluwafemi Emmanuel \\ Department Of Linguistics And African Languages, Obafemi Awolowo University, Ile-Ife, Nigeria \\ Department Of Linguistics And African Language, Obafemi Awolowo University, Ile-Ife, Nigeria
}

\begin{abstract}
Aspects of language use and attitudes among the contemporary Yoruba people as reflected in their naming practice, are the primary focus of this paper.The study primarily expounds the linguo-cultural uniqueness of Yoruba names with a view to highlighting their pragmatic and cultural importance.An approach comprising of empirical and descriptive approaches was adopted to showcase the prevailing sociolinguistic factors in the south western part of Nigeria eliciting the factors that are responsible for name dropping and change among the so-called Yoruba elites. It is found that lack of cultural understanding, unbridled incorporation of western cultureon the part of the young elitescoupled with reckless religious bigotry largely account for the people's negative attitudes towards the jettisoning of certain form of names. Conclusively, it is argued that name dropping and change are common sociolinguistic phenomena among the contemporary Yoruba elites and the situation should be stemmed or at least be sanitized, as it strongly portends strong linguistic alienation and culture subversion which are deemed to be devastating tosustainabledevelopments.
\end{abstract}

\section{Introduction}

Many scholars working on African anthroponomastics contend that African names reflects cosmological and socio-linguistic information encoded in varying surface linguistic structures basically for the purpose of identifying individuals in any given culture and society. (see Ayuwo2007:243,Iwundu(1994),Asoh and Aintono(2010:77),among others. Yoruba Personal Names(YPNs) in particular, are found to be contrived along the perspectives of memorializingthe understanding of human aspects of individualities. This is because names are found to be the verbal records of the conceptual details about the people's survival within their peculiar sociolinguisticenvironments (the cosmos and ecology). By and large, what we find in names seeks to account for how the people's profiles are packaged to ensure continuity by placating and appeasing the mysteries surrounding first, the procreation of the individuals and second, the human survival in the phase of his several struggles for existence, recognition and importance. Essentially, the abridged memoires of these accounts are the contents of the YPNs.

Although a well-known fact is that naming practice is a universal phenomenon, but the Yoruba anthropology however, distinguishes two distinctive pseudonyms for every individual. First is the one given at the pre-naming periodand the other is at the period after taking the last breathes on earth, not minding the gender. Every Yoruba child before naming is generally referred to asaròbó or túnfúlù before the naming day. And following the demise of every individual, the corpse is referred to as $i k u$ regardless the sex.A corpse,not minding its social class and age is renamed a $o k u$ and is no more to be referred to by his real personal name.

Another distinctive linguistic insights offered by theYPNsis that they point to the memorialisation of the people's(and community's) cultural identities, social and historical events, psychological heritage, distinct discourse roles and realizable hopes and aspirations of the peopleBabalọlá and Àlàbá (2003). Yoruba names, therefore, are observed to be linguistically couched in succinct phraseology to enable the words participate in discourse encounters and frameworks, seeOgunwale(2012a).

Furthermore, in an earlier work ${ }^{1}$,attempts were made to argue that YPNs surpass mere identification tags and that the names could be used to signal other sociolinguistic functions like those highlighted in the various discourse roles cited in the present author's earlier work. The observation was precipitated upon three premises. One: there is no monosyllabic Yoruba name in the language; even the abridged names( like Dàpọ̀,Jídé,Láyí,Sọlá,Sịkẹ,etc)still retain a minimum of two syllables and therefore make them capable of bearing arrays of meanings. Issues that are vital and fundamental to the Yoruba communicative experience are those lexicalized and couched in their name- words.

Secondly, there are certain socio-cultural inhibitions which put some restrictions ${ }^{2}$ on trivialities or none-culturally motivated words from participating in the naming system among the Yoruba people. Issues that are regarded as unimportant are not involved and are notmemorialized in naming. The degree of what counts is 
context and time bound. The context preferred could either be temporal, psychological,and geographical or could be two or more of the above contexts. The overall effect of this is that not all the words in the language vocabulary can be used as personal names. Dirty or vulgar words are barred.

And thirdly, based on the first factor, the abridged sentential name-words are either proverbial expressions or other aphorism- based expressions which had equally become couched over the years and had therefore become part of the language vocabulary. They might have kept changing in line with one or more spectrums of the language analysis. Quite often, hosts of them represent cases of vestige of diachchrony in the language vocabulary. For that singular reason, certain names appear outlandish and unappealing at least to the young folks. Ogunwale (2012d:14) observed that the reports of the features of such changes in YPNs are less critically reported in the language literature ${ }^{3}$. According to him, aspects so far reported only vaguelyfocused the cosmic factors of the Yoruba names as part of the enduring cultural heritage of the people. This is because the name Yorubapeople bear may endear or castigate a particular individual based on the societal negative stigma that might have been attached to such name in the past, either as a result of the religio-cultural factor or the past socio-political experience of the people. Naming among the people, therefore, can also be employed as a factor to establish series of differentiating capabilities in the linguo-cultural and contemporary political systems.

The preceding submissions attest to the fact that issues involved in the YPNs are so intriguing and complex that their analysis could provide a template for the identification of class structure among the people, racial identity, philosophy, societal ethics, probable line of migration, origin and their genealogy. In other words, the Yoruba people could be dialectally identified within the contexts of other societies on the bases of their beliefs in the meanings inherent in their names. As it will soon be demonstrated, the Yoruba names, within the context of African setting serve as a container which carries the meaning components of the people's dialectic views and cultural anthropology.

Besides, it needs be stressed from the outset that a substantial number of these names encode almost all the lexical properties of a sentence. Those whose structures do not overtly reflect sentential forms, however, can be said to have been either clipped or abridged to enable them qualify for the vocative expression which the name -words are supposed to serve. In addition, the apparent lexical format of names remains so with a view to obeying the length restriction principles which the name- words should also entail. These various restrictions are copiously expressed in Ekundayo (1977). More-over, the sentential structures in names have undergone the word boundary erasure in the process of their being lexicalised and reduced to word-forms. It is also contended that the sentential properties inherent in them are the basic backgrounds for their being used as ingredients of discourse formulation. More -over, it needs be noted that not all the YPNs are equally fruitful as lexical discourse because some names are tokens of metaphoric expressions .On the other hand, those names whose lexical configurations do not participate in the discourse role assignment as being discussed copiously represent the cultural treasure of the people. Examples of such names are those referred to as metaphoric names ${ }^{4}$ in an earlier study.

Based on the preceding assertions therefore, it is very apposite to outline the structures of the YPN forms and subsequently attempt a classification. Such an endeavour would make sense with the subsequent broad review of earlier works on African Onomasticsin general and YPNs in particular.

\section{Review of Earlier Works}

Scholarly articles have been written over the years on the various aspects of anthropo-onomastrics (the study of naming systems and practices) across the cultures and peoples of Africa. One intriguing factor about this plethora of studies is that there are many discernible issues in African names which make them stand out compared to what obtains in other cultural contexts outside the shores of Africa.(cfAnsu-Kyemerh (2000), Essien (1986),Ubahakwe (1982), among others).It is also argued that African names epitomised the linguistic and cosmic views about the people. Specifically, Onukawa (1998:73ff) opines that

An indigenous African name on the whole personifies the individual; tell some stories about the parents or the family of the bearers, and in a more general sense points to the values of the society in which in which the individual is born.

Africans therefore regard the bearer of a particular name as being potentially able to evince the characteristics contained in the semantic encodings of their names.

For example, Oyeleye (1985:137)impressively opines that 'in African society, a man's individuality is often summed up in the proper or personal names he bears .He goes further to illustrates his arguments with a number of characters found in some African literary works written in English. Speaking in the same vein, Oluikpe (2004:283) works on the Igbo Personal Names within the framework of a Generalised Pragmatic Interpretation where he contends that many Igbo cultural identities run into one another in terms of the wordviews articulated in them. Odebode (1985:199) also does a sociolinguistic analysis of Yoruba names and comes to the conclusion that names 'are indexes to characters and naming is part and parcel of African heritage' in the sense that the linguistic formats and the religio-cultural beliefs in names are transmitted from one generation to 
the other. Essien (1983:124) however, contends that naming among the Ibiobio and Yoruba could be likened to each other because they are similar in very many respects especially in their reference to cultural significance, psychological influence, and religious affiliation. Succinctly put, home condition is an essential consideration for giving a particular name to a child. Other scholarly works include Ekundayo (1976) and (1977) which are based on thesyntactic analytical approaches using the Yoruba name-structures to posit that lexical insertion is still possible in syntax even after transformation, thereby providing sufficient background to question the Chomskyian (1965) Lexical Insertion Theory. Akinnaso (1980) and Abiodun (1996) independently provide critical insights into the sociolinguistic structures of the Yoruba personal namesThese myriads articles therefore provide some vintage information on the analysis of African names within the contexts of sociolinguistics and cultural values. Furthermore, Adéniyi (1997) and Ògúnwálé (2003), attempt to expatiate the morphological structures of the Yoruba names and found that despite their composite structures, their tokens in the language do achieve both lexical and sentential status. The first reason which make this to be so is that the language mechanism employs the linguistic repertoires ofmorpho-syntax to derive the particular class of Yoruba sentential nominal which the name-words encode. Further- more, one can also findBabalọlá and Àlàbá (2003) very apposite as they have also provided useful insights on the lexicology of the Yoruba personal names, thus using the name forms to provide a lens through which the word- forms of the language could be determined.

Summarily, the above different scholarly works indicated that the known works on the YPNs can be patterned along the following parameters:

(i) the classification of the whole gamut of names into either cultural significance, Psychological importance, theophoric account, etc;

(ii) naming formatting i.e. classification of names into patrimony, surname, day-names, etc;

(iii) the semantic consideration i.e when the semantic effects of names are considered within the vocabulary;

(iv ) gender related issues in the naming system;

(v) the multiplicity of the name- form i.e synonymy in the naming system; where two names considered as a replica of another;

(vi) dynamism in the name forms and usages, i.e their elasticity in form of their structures and usages (pragmatics).

At varying depths in the literature, discussions on Yoruba names have been factored to address each of the above perspectives at one time or the other without necessarily alluding to how they are demeaned by social factors like religion, westerneducation, and culture subversion. The main contribution of this paper, therefore will be to demonstrate how the above factors affect the way Yoruba names are conceived, used, changed and dropped in preference to English, religious and social names. Similar attempts have been made on the textual essence of the Akan language where Ansu-Kyemerh (2000:20) explicated those issues he considered remarkable and worthy of been communicated in the language discourse of the Akan people.

\section{Anthropolinguistic Classification of Yoruba Names}

Several attempts have been made in the literature to delineate and class up the YPNs using different paradigms and instruments. Works such as that of Johnson (1969:87), Orie-Ola(2000:119) Odebode(2010:209),among others, can be cited. Succinctly put, however, the Yoruba names have been broadly classified as either given, ascribed and brought from heaven (seeFaturoti (2012:6).In modern times, the perspectives onnames havechanged. The present study will attempt to explore the reasons and the implications later in this study.

Besides, these studies identify the different characteristics of African names as being classified into given, ascribed or acquired and circumstantial(fixed and substitute) names. (See for example, AnssuKyeremeh,2000:19). Furthermore, the classification of African names into unique, given and pet names by Onukawa (1998:73)is also very apposite. The only difference is in term of their nomenclature because their illustrations on the communicative capacities run into each other The noticeable bottom line, therefore, is that arrays of cultural and sociolinguistic factors are packaged into name-words and consequently have some effects on their lexical and semantic structures .

Succinctly put, the Yorùbá principal names can be determined by five major factors. First, the name of the family divinity or totem used as the subject,plus the' action' that the divinity or totem has done with the birth of the child as the predicate. Example isògún(divinity/god of iron i.e.subject)Yemí (befits me i.e. the predicate). ọṣun (the goddess/ divinity of the river as the subject of the name)-kúnle (full the house, as the predicate)... wùmi' (attracts me) ...délé( arrives home)...túndé (comes again) as possible predicates . The second principal way is the name of a social item like Ọmọ (child),Ọlá ( honour) Oyè (chieftains). The predicate can take any of the italized forms taken by any of the preceding examples used for the totem. The third way is to depict a meaningful creation aiming at showing the unique or overbearing family incident or situation at the time of 
birth. For example, İfẹ́làjà (love resolves the quarrel), Ewéjé (herbs were efficacious)Abéjidé(one who arrives at the onset of rain)i.e during the rain of the year.The fourth principal factor is the automatic brand of names which is termed àmútọrunwá (brought from heaven). Examples are the names of twins (Táyé/Kẹhindé), (İgè) -a child with the legs coming out first,(Ojó) for a male child born with the umbilical cord around the neck. The last in this category is derisive /insultive or death-negating name given to the child who is believed to be an àbíkú (a child who dies repeatedly while still young),e.g.Kúkòyi (death rejects this)ẹlẹ́dẹ(pig)Ajá (dog)e.t.c.

And much besides ,Orie-Ola (2000:119)opines that Yorùbá full names ,like fingerprints,are unique to each person. Johnson (1969:87) speaking in the same vein says 'When the orukọ (name), the oríki and the orílè(totem)are given, the individual is distinctive, the family is known, and he can at any time be traced.The above explanations are succinctly depicted in Tables 1 to 3 below:

\section{The Tables Showing the Yoruba Personal Names}

TABLE 1: The Yorùbá Given Names

\begin{tabular}{|c|c|c|c|}
\hline Personal Names (Orúkọ Àbísọ) & Nicknames (Orúkọ Àlàjẹ́) & $\begin{array}{l}\text { Attributive Names } \\
\text { (Oríkì̀̀bísọ) }\end{array}$ & Totemic Names (OríkìOrílẹ) \\
\hline Ọláníkẹeẹ $(\mathrm{F})$ & Awẹ́lẹ́wà (M) & Àkànbí (M) & ÀkànbíÓdí \\
\hline Oyèníyì (M) & Eyínoge (unisex) & Àríkẹ́ (F) & Àríkẹ İkó \\
\hline Kọ́láwọlé (M) & Agẹnjó (M) & Àjàó (M) & ÀjàóĖșó \\
\hline Morẹnikẹe (F) & İbàdí-àrán $(\mathrm{F})$ & Àmọ̀kẹ́ (F) & Àmọ̀kẹ́ Ẹdú \\
\hline
\end{tabular}

TABLE 2: The Yorùbá Ascribed Names

\begin{tabular}{|l|l|l|}
\hline Epithetic/Proverbial Names (Orúkọ İnagijẹ) ) & $\begin{array}{l}\text { Junior Wive's Invented Names } \\
\text { (Orúkọ Àdàpè) }\end{array}$ & Apellations (Orúkọ Àníjẹ́) \\
\hline Ànjọ́nrìn & Arówólò & Àgòrò \\
\hline Bólódeòkú & Ayílukọ & Akóredé \\
\hline Apálará & Akọ́we & Aríjẹ \\
\hline Àjùmọ̀bí & Ajísafẹ́ & Ọwọsọ \\
\hline
\end{tabular}

TABLE 3: The Yorùbá Pet Names

\begin{tabular}{|l|l|l|l|}
\hline $\begin{array}{l}\text { The Molyfying Type (Orúkọ } \\
\text { Èbẹ) }\end{array}$ & $\begin{array}{l}\text { Do-your-worse Type } \\
\text { (Orúkọ Sèyî́-ó-wù-ọ́) }\end{array}$ & $\begin{array}{l}\text { Dirty/condemnable Names } \\
\text { (Orúkọ Ajẹmọ Ègbin) }\end{array}$ & $\begin{array}{l}\text { Assertive Names } \\
\text { (Orúkọ Amọ́kànle ) }\end{array}$ \\
\hline Bámtàlẹ́ & Akísàtán & Elẹ́dẹ & Kúkọ̀yí \\
\hline Jókòótọlá & Kòsọ́kọ́ & Ajá & Igbẹ́kộyí \\
\hline Mámàálọ & Kílànkó & & Kòkúmọ́ \\
\hline Bámjókòó & & & Mákùú \\
\hline
\end{tabular}

\section{The so-called Yoruba socio-elites}

The corps of Yoruba social elites emerged with the advent of western education in Nigeria in the wake of eighteenth century. This new crop of African elites began to see themselves as being different, and they not only felt more superior to their kith and kin who have not tasted western education like them, but theyfelt dignified, proud and contented with anything exotic. Native cultures weredebased remarkably. To be specific, the way the contemporary elites drop their names or substitute the principal words within the name-words with something else(for reasons of modernity and religion)displaces the traditional essence of naming among the people such that thesociolinguistic dislodgement made naming to lose its worth considerably. For example, the elite parents prefer English rendering of certain names to its Yoruba equivalence e.gBlessing,Joy,Mercy and Fortune are preferred to İbùkùn,Ayọ̀, Áánú, Oríirerespectively. These spates of linguistic alienation continue to be evident in several other stratums ofthe society-educational, religious and economic lives of the people. Incidentally, the Yoruba were among the first set of people to have contacts with the Europeans. As time went on, the heavy functional load of English in Nigeria permeated through their socio-economic lives as highlighted in Quirk etal (1985:4) thus:

(i) Instrumental factors for formal education purposes. In Nigeria today, English being the national language is incorporated into the school curricular right from the primary up to the tertiary institutions - University and Polytechnics. In private primary and secondary schools, it turns to be an anathema for students to speak in the native languages.

(ii) Regulative device for government in administration and law courts. English is used for different circulars in all government parastatal. Judgments are delivered in courts of law even if the litigants do not understand English or are able to interpret the article of law to which they have been liable and accused. In many homes (among the children and their parents) and family meetings, English is preferred.

(iii) Communicative for interpersonal communication between the individuals speaking different native languages. Also, English language is used as a common code which facilitates all forms of communications between different strata of people. This use is considered the greatest. 
(iv) Occupational, both intra-nationally and internationally for commerce and for science and technology. Quirk etal (1985:6) observes that "not only is English the universal language of international aviation, shipping and sport, it is to a considerable degree the universal language of literacy and public communication".

(iv) Creative purposes for non-technical writing such as fiction and political works. People of different social class are involved here. In the use of text messages, bill-boards and announcements in electronic and print media.

The above forms the sociolinguistic environments which negatively articulate the exit of cultural values of which naming is a victim. The Yoruba(Africans)elites therefore, prefer foreign music, foreign names, refuses to assert their Africaness but imbibe foreign mode of dressing as if none is native to them. Africans refuse to "decolonize themselves" by not giving the local languages the socio-economic and educational status which are germane to their contemporary lives and subsistence. The resultant effects are that this undue alienation and wrong social preference have serious devastating effects on thepeople'selfactualization,localindustry,participatory democracy and the economy.

Furthermore, Owolabi (2008:43), specifically reports the general language attitudes of the Yoruba elites (a highly cosmopolitan tribe in Nigeria), which are also considered a replica of what can be found among other contemporary African peoples, in the following excerpt:

(a) parents do not expose their children to the mother tongue well enough by communicating with the children using their mother tongues. Most nursery and primary schools neither teach it nor allow their pupils to speak in it. As a result, the language is fast becoming a moribund civilization;

(b) as a result, the elites can no more speak the language proficiently without code - switching and whereas they go about flaunting this inadequacy in the public as being normal;

(c) the aged are the only set of people left with the speaking of the language in public in our contemporary time;

(d) there is paucity of local languages in print media in the society;

(e) the vocabulary of the language is presently inadequate and thus unable to cope with the growing socio- economic needs and demand, yet the government's attitude is nonchalant;

(f) indigenous practices, which have linguistic bases in form and content, are fast changing phases to take on new look and foreign perspectives, e.g. naming, form of greetings, music, native intelligence, e.t.c. English names are fast becoming the vogue even when there are equivalences of these names in the native languages;

(g) translation of the existing pamphlets on jurisprudence, court proceedings broadcasting, citizenship, human right issues ,povertyalleviation, e.t.c, into

local languages are left undone and so remain in English language; the

language of the colonial master.

The above scenario make the new generation of young adults disdain anything considered to be indigenous; linguistic, social attitudes, food, clothing etc. Of particular relevance to this study is the way these young elites drop and change their names.

\section{Statement of the Problem}

\section{The study}

The rates at which Yoruba people change or drop their names either after a new appointment in the government establishments or at the point of registration in tertiary institutions are quite remarkable. These are not only worrisome but are also prone to suspicion, fraudulence and administrative dislocation.

\section{The purpose of the Study}

The main objectives of this study, therefore, were to

i. investigate the underlying factors that are responsible for the changes or the innovations that may occur in personal/official names of the subjects

ii determine those factors that are deemed to be linguo-culturally motivated

iii to stem the tide of linguistic alienation and culture subversion that may be associated withthe practice

\section{Significance of the Study}

Students, teachers and other government workers do engage in name dropping and change at will and there has not been any proper investigation specifically focused on the sociolinguistic factors that are 
accountable to our knowledge. The study therefore, becomes necessary as the outcomes could help to enhance people's interests in native language names on one hand, and help to sanitize the social system by ensuring that appropriate capacity building in government establishments is ensured instead of engaging in fraudulent practices of proxy ; using other people's credentials.

\section{Research Hypothesis}

- Name givers do not mean anything serious about the content of the names given to their children

- Most name bearers do not understand the semantic imports of their names

- Names generally have no meaning

- Names could be dropped and changed at will if one can do all necessary propagandas

- Most people change/drop their names in order to copy others around them

\section{Research Methodology}

A total number of 250 respondents are involved in this study,sampled in the south-western geopolitical zone of Nigeria.This was because the zone harbours the linguistic cradle of the people and secondly, they are greatly influenced by western culture and civilization. The methodology employed in this study hinge on two major approaches: Focus Group Discussion (FGD) and In-depth Interview (IDI). These two approaches are deemed essential for the understanding of the socio-linguistic factors responsible for name dropping and change among the Yoruba elites in Nigeria. These two approaches and other related details are discussed in the ensuing sections.

a. Focus Group Discussion (FGD) guidelines. This approach is adopted with the aim of identifying the range of social vulnerabilities that Yoruba elites, women and youths are facing at both urban and rural settings as a result of either religion, culturesubversion, linguistic alienation, ethnicity and age groups in respect of name dropping and change in the society.

b. In-Depth Interviews (IDIs).This methodology is also employed within the community members with the aim of exploring in details how different categories of the sampled population are affected by name dropping and change and how their responses vary accordingly.

These instruments were supported by field surveys specifically the youths in the rural and urban centers. The survey was non-probabilistic and purposive in the selective sampling in all the categories of respondents. The following activities assisted in setting out a detailed methodology, designing and refining the data collection instruments:

\section{Stage 1: Inception workshop}

There was a capacity building workshop of research team where discussion of key concepts, terms and methods were explained and thoroughly taught. The inception workshop segued into piloting of the data collection tools.

\section{Data collection}

The data collection approach for the study was the Focus Group Discussion (FGD) and In-depth Interview (IDI).

a) Focus Group Discussion: A reasonable number of Focus Group interviews will be held across six Yoruba ethnic groups in the South-West geo- political zones of Nigeria with the Youths, Students, Religious organisation, Women and the Elites. Focus Group Discussion (FGD respondents included members of religious groups, ethnic groups, social groups, community leaders and/or representatives of women's group and / or other groups.

b) In-Depth Interviews : In addition, Two Hundred and Fifty (250) IDIs was held across the sixYoruba ethnic groups in the South-West geo- political zones of Nigeria. Criteria for selection of respondents followed a life cycle approach, with the aim of observing males and females at three stages (adolescence, adulthood, elderly). Interviewees were engaged in varied reasons for name dropping and change among the Yoruba in Nigeria.

A non-probabilistic and purposive selective sampling frame was adopted to track various reasons for name dropping and change among the Yoruba social groups. The selection criteria were aimed at capturing major factors influencing name dropping and change. The technique focused on the various transmission mechanisms through which religion, marriage and peer groups have influenced decision on name dropping and change among the Yoruba. There shall also be a Content analysis of the qualitative data to identify themes, sub-themes and categories of respondents. 


\section{Statistical techniques}

The studyconducted interviews with the stakeholders in the states where name dropping and change among the Yoruba race in Nigeria is considered prevalent. Qualitative methods of analysis were used on the relevant materials collected. The study relied mostly on descriptive analysis to bring out the stylized facts from the study.

The data analysis phase will commence with manual and electronic transcriptions of the in-depth interview guide. This was followed by the entering of the data into the computer using the SPSS software. This database software can be read in other statistical packages such as SPS. The Statistical Package for Social Scientists (SPSS) is the main statistical software was employed in the analysis of the data generated. This package was employed in generating frequencies such as means, standard deviations, etc. Other relevant descriptive statistics was also generated using the software. In addition, tables and charts were also employed in displaying the results of the data obtained from the field.

\section{Research Questions/ Focus Group Discussion.}

Name of Respondent (optional):

Position/Designation:

Town: State: Ethnic Group:

1. How can you assess the level of change of name in the state?

2. Why, in your own view, do people change name?

3. Give further reason(s) for your answer in Q2 above.

4. What can you say about name dropping among people nowadays?

5. What dialectal group do you belong to among the Yorubas?

6. Give reason(s) for your answer in Q4 above.

7. Do you consider anything wrong with name dropping and change?

8. How can you assess the rate of name dropping among men in your society?

9. Will you say name dropping is peculiar with a particular gender?

10. Give reason(s) for your answer in Q8 above.

11. Women are known to drop maiden name after marriage, Are Men are also dropping names?

12. What are the major reasons why Men are dropping name nowadays?

13. Do you see religion as a factor influencing name dropping and change?

14. Can you ascertain the effect of cultural values in name dropping and change?

15. Do you experience high incidence of name dropping among your ethnic group?

16. In your own opinion, which of the age category are most vulnerable to name dropping?

17. Why is it common among this age category mentioned in Q16 above?

18. Are you aware of the rising tide in name dropping among a particular academic qualification?

19. Why is it common among the academic qualification mentioned in Q18 above?

20. Have you seen or noticed any significant impacts of being rural dwellers to drop or change name except by marriage?

21. Where will you say name dropping is most common, rural /urban?

22. Give reasons for your answer in Q21?

23. Which of the social factors influence name dropping most?

24. What are your reasons to your answer in Q23?

25. Will you attribute name dropping and change to value system in the society?

26. Give reasons for your answer in Q25

27. Is there any significant benefit in name dropping and change?

28. What are these benefits if any?

29. Do parents play any significant role in name dropping and change?

30. What are your reasons to Q29? 
Data Showing the Sociolinguistic Factors Influencing Name Dropping and Change among the Yoruba Elites.

\begin{tabular}{|c|c|c|}
\hline Category & Freq u en CI & Percentage \\
\hline & $N=250)$ & (Total=100) \\
\hline $\begin{array}{l}\text { Gender } \\
\text { Male } \\
\text { Female (Marriage) }\end{array}$ & $\begin{array}{l}12 \\
238\end{array}$ & $\begin{array}{l}4.8 \\
95.2\end{array}$ \\
\hline $\begin{array}{l}\text { Agegroups } \\
20-30 \text { years } \\
31-40 \text { years } \\
41-50 \text { years } \\
\text { Above } 50 \text { years }\end{array}$ & $\begin{array}{cc} & 148 \\
& 55 \\
24 & \\
& 23\end{array}$ & $\begin{array}{l}59.2 \\
22.0 \\
9.6 \\
9.2\end{array}$ \\
\hline $\begin{array}{l}\text { Education } \\
\text { No School At All } \\
\text { Primaryeducation } \\
\text { Secondaryeducation } \\
\text { Highereducation }\end{array}$ & $\begin{array}{c}7 \\
58 \\
107 \\
78\end{array}$ & $\begin{array}{l}2.8 \\
23.2 \\
42.8 \\
31.2\end{array}$ \\
\hline $\begin{array}{l}\text { Religion } \\
\text { Islam } \\
\text { Christian } \\
\text { Traditionalreligion }\end{array}$ & $\begin{array}{c}96 \\
143 \\
11\end{array}$ & $\begin{array}{r}38.4 \\
57.2 \\
4.4\end{array}$ \\
\hline $\begin{array}{l}\text { Culture } \\
\text { Parental Influence } \\
\text { Linguistic Alienation } \\
\text { Culture Subversion } \\
\text { Per group Influence }\end{array}$ & $\begin{array}{c}75 \\
48 \\
32 \\
85\end{array}$ & $\begin{array}{l}30.0 \\
19.2 \\
12.8 \\
34.0\end{array}$ \\
\hline $\begin{array}{l}\text { Sector } \\
\text { Urban } \\
\text { Rural }\end{array}$ & $9_{92}^{158}$ & 63.2 \\
\hline $\begin{array}{l}\text { Dialects/Ethnicity } \\
\text { Oyo } \\
\text { Ijesha } \\
\text { Egba } \\
\text { Ekiti } \\
\text { Ondo } \\
\text { Ijebu } \\
\text { Peer group Influence }\end{array}$ & $\begin{array}{l}52 \\
48 \\
41 \\
39 \\
33 \\
37 \\
85\end{array}$ & $\begin{array}{c}20.8 \\
19.2 \\
16.4 \\
15.6 \\
13.2 \\
14.8 \\
14.4 \\
32.8\end{array}$ \\
\hline
\end{tabular}

\subsection{Findings:EmpiricalResultsand Discussion}

Table 1: Percentage Distribution of Name Dropping and Change by Age Classification

\begin{tabular}{|c|c|c|}
\hline Category & Frequency & Percentage \\
\hline Agegroups & 148 & 59.2 \\
$20-30$ years & 55 & 22.0 \\
$31-40$ years & 24 & 9.6 \\
$41-50$ years & 23 & 9.2 \\
Above50years & $\mathbf{2 5 0}$ & $\mathbf{1 0 0 . 0}$ \\
\hline Total & & \\
\hline
\end{tabular}

Source: Field Survey 2013.

Table 1 above showedthe percentage distribution of name dropping and change by their age classification. Arisingfromthetable, out of a total of 250 respondents, 148 within the range of between 20 and 30 years category $(59.2 \%$ )were found to be involved mostly in name dropping and change. The least in name dropping and change was the 50 years and above category with just $9.2 \%$. This showed that name dropping and change were not very common among the Adults. It was also found that the 20 to 30 years category was closely followed by the 30 to 40 years category which implies that name dropping and change are common among the youths. 
Table 2: Percentage Distribution of Name Dropping and Change by Educational Qualification.

\begin{tabular}{|l|l|l|}
\hline Category & Frequency & Percentage \\
\hline Education & 7 & 2.8 \\
No School At All & 58 & 23.2 \\
Primaryeducation & 107 & 42.8 \\
Secondaryeducation & 78 & 31.2 \\
\hline Highereducation & $\mathbf{2 5 0}$ & $\mathbf{1 0 0 . 0}$ \\
\hline Total & & \\
\hline
\end{tabular}

Source: Field Survey 2013.

Table 2 above showedthe percentage distribution of name dropping and change by their educational qualification. Arisingfromthetable, out of a total of 250 respondents, 107 respondents with secondary education category $(42.8 \%$ )were found to be mostly involved in name dropping and change. This category was strictly followed by the Tertiary education qualification category with 78 respondents $(31.2 \%)$ The least category in name dropping and change was Never Attended School category with just 7 respondents $(2.8 \%)$ involving in name dropping and change.This showed that name dropping and change were not very common among Never Attended School category .

Table 3: Percentage Distribution of Name Dropping and Change by LinguisticAlienation and Culture Subversion.

\begin{tabular}{|l|c|c|}
\hline Category & Frequency & Percentage \\
\hline Culture & 75 & 30.0 \\
Parental Influence & 48 & 19.2 \\
Linguistic Alienation & 32 & 12.8 \\
Culture Subversion System & 85 & 34.0 \\
\hline Peer group Influence & & $\mathbf{1 0 0 . 0}$ \\
\hline Total & $\mathbf{2 5 0}$ & \\
\hline
\end{tabular}

Source: Field Survey 2013.

Table 3 of the analysis showedthe percentage distribution of name dropping and change by cultural factors. From the table, peer group influence dominates in the cultural factors influencing name dropping and change. Arisingfromthetable,out of a total of 250 respondents, 85 respondents gave peer group influence $(34.0 \%)$ as the most dominant factor influencing name dropping and change. This factor was strictly followed by parental influence factor with 75 respondents $(30.0 \%)$ The least factor according to the survey report in name dropping and change was cultural value system with just 32 respondents $(12.8 \%)$ practising name dropping and change.. This showed that name dropping and change were not determined significantly by the cultural value system factor.

Table 4: Percentage Distribution of Name Dropping and Change byDialects/ Ethnic Group Factors.

\begin{tabular}{|c|r|r|}
\hline Category & Frequency & Percentage \\
\hline Ethnicity & 52 & \\
Oyo & 48 & 20.8 \\
Ijesha & 41 & 19.2 \\
Egba & 39 & 16.4 \\
Ekiti & 33 & 15.6 \\
Ondo & 37 & 13.2 \\
Ijebu & $\mathbf{2 5 0}$ & 14.8 \\
\hline Total & & $\mathbf{1 0 0 . 0}$ \\
\hline
\end{tabular}

Source: Field Survey 2013.

Table 4 of the analysis showed a very interesting result. The percentage distribution of name dropping and change by ethnic group factors depicts that it cuts across all the Yoruba ethnic groups.Arisingfromthetable, out of a total of 250 respondents, Oyo dialect group dominates allother ethnic groups in the practice. This was followed by the Ijesha and Egba with 52 respondents $(20.8 \%), 48$ respondents (19.2 $\%$ ) and 41 respondents (16.4\%) respectively. This was followed by Ekiti 39 respondents (15.6 \%), Ijebu 37 respondents $(14.8 \%)$ and Ondo 33 respondents $(13.2 \%)$ in that descending order. This showed that name dropping and change were actually present among all ethnic groups of Yoruba race. It is not peculiar to a particular ethnic group. 
Table 5: Percentage Distribution of Name Dropping and Change by Religious Factors.

\begin{tabular}{|l|l|l|}
\hline Category & Frequency & Percentage \\
\hline Religion & 96 & 38.4 \\
Islam & 143 & 57.2 \\
Christian & 11 & 4.4 \\
Traditionalreligion & $\mathbf{2 5 0}$ & $\mathbf{1 0 0 . 0}$ \\
\hline Total & & \\
\hline
\end{tabular}

Source: Field Survey 2013

Table 5 above showedthe percentage distribution of name dropping and change by religious classification. Arisingfromthetable,out of a total of 250 respondents, 143 respondents gave Christianity $(57.2 \%)$ as their religion and they were found to be involved in name dropping and change. The least in name dropping and change was the Traditional Religion adherents with just 11 respondents (4.4\%). Although Moslems also practice Name dropping with 96 respondents (38.4\%), it was not as high as that of their Christian counterpart .This showed that name dropping and change were not very common among the Traditional Religion practitioners.

Table 6: Percentage Distribution of Name Dropping and Change by Gender Factors.

\begin{tabular}{|l|l|l|}
\hline Category & Frequency & Percentage \\
\hline Gender & 12 & \\
Male & 238 & 4.8 \\
Female (Marriage) & $\mathbf{2 5 0}$ & 95.2 \\
\hline Total & $\mathbf{1 0 0 . 0}$ \\
\hline
\end{tabular}

Source: Field Survey 2013

Table 6 above showedthe percentage distribution of Name Dropping and Change by Gender factors. Arisingfromthetable, out of a total of 250 respondents, 238 respondents were Females ( $95.2 \%)$. Theywas also found to be involved in name dropping and change. This was attributed to marriage as a dominant factor because when any female got married, she is bound by law and social ethics to drop the maiden name. The least in name dropping and change was their male counterparts with just 12 respondents (4.8\%).As low as this percentage is, it is still intriguing because one wonders as to the genuineness of their claims. The males on the other hand change name or drop name as a result of religion and other social factors. This showed that name dropping and change were very common among the Female folk in Yoruba land.

Table 7: Percentage Distribution of Name Dropping and Change by Sector.

\begin{tabular}{|l|r|r|}
\hline Category & Frequency & Percentage \\
\hline Sector & 158 & \\
Urban & 92 & 63.2 \\
Rural & $\mathbf{2 5 0}$ & $\mathbf{1 0 0 . 0}$ \\
\hline Total & & 36.8 \\
\hline
\end{tabular}

Source: Field Survey 2013

Table 7 above showedthe percentage distribution of Name Dropping and Change by sector.Arisingfromthetable, out of a total of 250 respondents, 158 of the respondents gave the Urban $(63.2 \%)$ to be practising more name dropping and change. This was attributed to urbanisation and socialisation of the population mix in the urban areas.The least category of people involved in name dropping and change was the Rural dwellers social group with just 92 respondents ( $36.8 \%$ ). This showed that name dropping and change were very common among the Urban dwellers in Yoruba land.

\section{Conclusion}

As peoples across all cultures grapple through their cultural heritage to put certain mechanisms in place in order to memorialize their past and actualizetheirculturalidentities. Deliberatefrantic efforts are made to appropriate aspects of thepeople's past biographies as a way to re-invent their cultural heritage and cast pithy expressions that will foreshadow their future aspirations. These are found to be made possible through the interpretation and actualization of the semantic imports inherent in naming- an embodimentof cultural memoires found to be replete with culturalvalues. But for the reasons of religious bigotry,western education, quest to shift 
from one social class to the other, massive urbanization which engender peer group influence, some Yoruba social elites change and drop their names at will. This has been observed to have some devastation effects on the cultural values and perceptions of the Yorubapeople, including linguistic alienation and culture subversion. On the contrary,efforts should be correspondingly and appreciably pursued by the so called Yoruba social elites of the south western part of Nigeria to re-gain their value systems as a way to save the younger generations from totallost. There are therefore convincing reasons why individual people should live by their culture especially, as contained in the name-words

\section{References}

[1]. Abiodun, M .A (1996), On the Most Valued Social Concept in Yoruba Names.Inquiries in African Languages and Literatures. Ado- Ekiti. Pp 44-52.

[2]. Adeniyi, H. (1997), Phrasal Morphology: The Case of Yoruba Names. South African Journal of African Languages. 17:4 pp 115-117

[3]. Adeoye,C.L .(1969), OrukoYoruba.Ibadan:Caxton Press

[4]. Allan, K. (1986), Linguistic Meaning. Vol. 1\&2 London: Rutledge and Kegan Paul Pls.

[5]. Akinnaso, F.N.(1980) The sociolinguistics Bases of Yoruba Personal Names Anthropological Linguistics.22,275304.

[6]. Ansu-Kyemerh K. (2002), Communicating Nominatim : Some Social Aspects of Bono Personal Names .Research Review Series. 16:2,19-33

[7]. Austin, J. L (1962), How Do We Do Things With Words. Cambridge: Mass, Harvard University Press.

[8]. Ayuwo,J.G.I(2007), OboloTheopheric and Ideational Anthroponyms. The Nigerian Linguistic Festschrift Series No 5,pp243-250

[9]. Babalola, A and Alaba O. (2002), A Dictionary of Yoruba Personal Names. Lagos: West African Book Publishers Ltd.

[10]. Chomskey, N. (1965), Aspect of theory of Syntax .Cambridge .Mass. MIT

[11]. Cole, P. and P. Morgan J (eds.)(1975), Syntax and Semantics 3.Speech Acts :New York Academic Press

[12]. Ekundayo S.A. (1976), An Alternative to Lexical Insertion for Yoruba Complex Nouns.Studies in African Linguistics. Los Angeles.7, 3:55-77.

[13]. (1977), Restriction on personal Name Sentences in the Yoruba Noun Phrases.Anthropological Linguistics, 19:2. Pp. $55-77$.

[14]. Essien.O. (1986),Ibiobio Names: Their Structure and Their Meanings. Ibadan : Day Star Press.

[15]. Ezikeojiaku, P. A.(2001),Discourse and Pragmatics Analysis of West African Oral Verse: The Example of the Ritual Poetry.Advances in African Languages, Literature and Culture.Lagos : Sam Orie C.A. Ogbulogo,E,P.AEzikeojiaku and Alaba O. (eds)pp87-109

[16]. Faturoti, 2013), Ayipadatiodeba IloA won Oruko Amutorunwa Yoruba Unpublished Manuscript Gaibreath,J.(2000),Knowledge Management Technology in Education.An Overview EducationalTechnology,40(5).

[17]. Gleeson,A.C.(20001),Information Seeking Behaviour of Scientists and Adaptation to Electronic Journal.Retreaved from http://itsunc.edu/mspape.

[18]. Johnson, Samuel, (1969), The History of the Yorubas.Lagos:CSS Bookshops Iwundu,M.(1994),A Socio-semantic Analysis of Igbo Anthroponyms. University of Nsuka,Ph.DThesis

[19]. Nso.A.E and S.A.Aintono(2010),Personal Names Among Sarefari Speakers of Northern Ghana.Journal of African Cultures and Languages .Department of Ghana LangugeEducation.University of Education, Winneba.

[20]. Obieng, S. G.(2001), On Ethnopragmatic and Morphological Study of Personal Names in Akan Societies. Lincom Studies in Anthropology .Muechen : Germany

[21]. Odebode ,I. (2005), A Pragmasociolinguistic Study of Names and Nicknames in Soyinka's Death and the King's Horseman. In perspectives on Language and Literature. Moji Olateju (eds) Ile Ife: Obafemi Awolowo Press.

[22]. Olatunji,O.O.(1984),Features of Yoruba Oral Poetry.Ibadan:University Press Ogunwale, J.A (2003),ÌhunàtiÌtumọ̀ÀwọnWúnrẹ̀nOrúkọAẹ̣ọ́ -ẹniàtiAjẹmọ́ -ibi NínúĖdèYorùbá.ỌbáfẹmiAwólộoọ.Ph .D Thesis.

[23]. Ogunwale,J.A.(2012a), Reflection of Dicourse Role Assignments in the Configuration of Yoruba

[24]. Personal Names.Mediterranean Journal of Social Sciences., Italy.Vol.3,No13,pp174-187

[25]. Ogunwale,J.A.(2012b), Tokens of Metaphorical Extension in Yoruba Personal Names .Matatu:Focus in Yoruba Literature and Culture.Germany.No40,pp361-373

[26]. Ogunwale,J.A.(2012c), A Pragmalinguistic Study of Yoruba Proverbial Names. Journal of Literary Onomastic Studies.Vol.2.pp New York

[27]. Ogunwale, J.A.(2012d),Evidence of Language Change: the Case of Vestige ofDiachrony in the Yoruba Personal Name words.NOVA Science publishers.

[28]. Oluikpe B. (2004), Igbo Personal Names :AGeneralised Pragmatic Interpretation Kola Owolabi and AdemolaDasyva (eds) Forms and Functions Of English and Indigenous Languages. Ibadan: Group Publishers. Pp182 -395. 
[29]. Onukawa,M.C. (1998), An Anthropolinguistic Study of Igbo Market -Day Names.Journal of AfricanCultural Studies, Vol.11,No1 Pp73-83.

[30]. Orie-Ola, N. (2002), Yoruba Names and Gender Marking.Anthropological Linguistics Indiana University, Bloomington.vol 44 no2, pp. 115-142.

[31]. Owolabi K. and Dysiva A. (2004), Forms and Functions of English and Indigenous Languages in Nigeria.Fescrift in Honour of Ayo Banjo.Ibadan : Group Publishers.

[32]. Oyeleye , A.L. ,(1982), The Language of Achebe 's Early Novels: A Study in literary Stylistics Ph.D thesis. OAU, Ile Ife.

[33]. Ubahakwe, E. (1981),Igbo Names : Their Structure and their Meanings. Ibadan: Daystar Press.

[34]. Yule .E. (1996), Pragmatics.Oxford University Press.

\section{End Notes}

1. See Ògúnwálé (2003) İhunàtilttumòÀwonWúnrènOrúkoAjemó-eniàti Orúko Ajemó ibinínúĖdèYorùbá.

2. For example, if the parents bought a new dress, new car, etc.,they cannot be part of the consideration to be included in name words.

3. This is however being undertaking by the present author in "Evidence of Language change: the Vestige of Diachrony in Yoruba personal Name form".

4. See Ògúnwálé (2012b) Tokens for metaphoric extension in Yorùbá Anthroponymes.

5. See Ògúnwálé (2010) A pragmatic Study of Yorùbá Proverbial Names.

6. This additional information is gleaned from http://plato.stanford.edu/entries/speech-acts. 